International Journal of Instruction e-ISSN: 1308-1470 • www.e-iji.net

Article submission code: 20191014060905

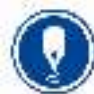

January $2021 \bullet$ Vol.14, No.1

p-ISSN: 1694-609X

pp. 85-104

Received: 14/10/2019

Revision: 05/06/2020
Accepted: 26/06/2020

OnlineFirst:10/10/2020

\title{
Eliminating Misconceptions on Reaction Rate to Enhance Conceptual Understanding of Chemical Equilibrium Using EMBE-R Strategy
}

\section{Jusniar Jusniar}

Chemistry Department, State University of Malang \& State University of Makassar, Indonesia, jusniar@unm.ac.id

\section{Effendy Effendy}

Chemistry Department, State University of Malang, Indonesia, effendy.fmipa@um.ac.id

Endang Budiasih

Chemistry Department, State University of Malang, Indonesia, endang.budiasih.fmipa@um.ac.id

\section{Sutrisno Sutrisno}

Chemistry Department, State University of Malang, Indonesia, sutrisno.kimia@um.ac.id

The objective of this study is to compare the effectiveness of EMBE-R and verification strategies in eliminating the rate of reaction (RR) misconceptions on different scientific reasoning capabilities (SRC) and improving students' understanding of concepts in chemical equilibrium (CE). This quasi-experimental design involved two homogeneous classes. One class taught using EMBE-R strategy, while the other class prepared with a verification strategy. Students' misconceptions in RR identified using a three-tier test, understanding of concepts in CE using a subjective test, and SRC using the scientific reasoning test. The percentage of RR misconception elimination using EMBE-R strategy with a high and low-level SRC is 76.7 and 72.3, whereas in verification strategy is 61.1 and 32.4. Students' understanding of CE showed a significant difference with the t-test. The average scores for EMBE-R and verification strategies, respectively 73.8 and 62.4. EMBE-R strategy is more effective than verification in eliminating students' misconceptions in RR. Elimination of misconceptions for students with a highlevel is easier than a low-level of SRC. EMBE-R strategy produces a better understanding of concepts in $\mathrm{CE}$ than verification. Application of EMBE-R strategy is highly recommended in teaching other chemistry materials having the same characteristics since this strategy is effective in eliminating misconceptions of prerequisites and produces a better students' understanding of new related concepts.

Keywords: elimination of misconception, rate of reaction, EMBE-R and verification strategies, chemical equilibrium

Citation: Jusniar, J., Effendy, E., Budiasih, E., \& Sutrisno, S. (2021). Eliminating Misconceptions on Reaction Rate to Enhance Conceptual Understanding of Chemical Equilibrium Using EMBE-R Strategy. International Journal of Instruction, 14(1), 85-104. https://doi.org/10.29333/iji.2021.1416a 


\section{INTRODUCTION}

Chemical Equilibrium (CE) is seen as the most difficult level material according to a survey conducted by chemistry teachers in the United States (Finley et al., 1982). This fact supported by studies reporting students' difficulties and misconceptions in almost all concepts within CE (Karpudewan et al., 2015; Yakmaci-Guzel, 2013; Barke et al., 2009; Özmen, 2008; Bilgin \& Uzuntiryaki, 2003; Niaz, 1998a). One of the causes is related to the characteristics of $\mathrm{CE}$ material, which are generally defined concepts derived from abstract objects or events (Ertmer et al., 2003; Effendy, 2002). Defined or abstract concepts tend to be well understood by students who have developed Scientific Reasoning Capability (SRC) (Gurcay \& Gulbas, 2018; Herron, 1996). However, several studies show that there are only $41-70 \%$ of students over the age of 12 years who have developed their SRC well (Mary \& Gumel, 2015; Bird, 2010; Abraham et al., 1994). Whereas those who have not developed their SRC well tend to have a low conceptual understanding and are more likely to experience misconceptions. This indicated by the results of a study of the relationship between SRC and students' misconceptions. (Lawson \& Thompson, 1988).

A misconception in the field of chemistry is supposed to be a severe problem as it would potentially contribute a negative impact on subsequent learning of more advanced related concepts (Paphothis \& Tsaparlis, 2008). In chemistry, concepts are interrelated (O'Connor, 2015; Seery, 2009; Effendy, 2002). Thus, failure in comprehending basic concepts or prerequisite concepts tends to give difficulty in understanding of subsequent topics (Ambrose et al., 2010). Knowledge of prerequisite concepts is an essential variable in the chemistry learning process (Ilyas \& Saeed, 2018; Durmaz, 2018; Bilgin \& Uzuntiryaki, 2003). If a student fails to connect the prerequisite concepts with another new concept, they will have difficulties in comprehending the new concepts (Taber, 2009). If it consistently happens to students, they would potentially experience misconceptions, that is, the understanding of concepts that are not by following that developed by the experts (Barke et al., 2009; Herron, 1996). This emphasizes the importance of eliminating students' misconceptions of prerequisite materials before starting to learn a new concept.

Concepts in Rate of Reaction (RR) are prerequisites in an understanding of concepts in CE. The students need to have a prover understanding of prior knowledge about RR before learning CE (Ganesen \& Shamuganathan, 2017). For instance, the concept of the forward reaction, reverse reaction, and reaction rate underlie an understanding of equilibrium constants (K). Collision theory is the basis for understanding the dynamic equilibrium concept. Factors affecting RR are required to understand the shift of equilibrium. Thus, a misconception of concept in RR is likely to result in failures to understand concepts in CE. In this case, students' prior knowledge is an essential source of students' misconceptions (Shing \& Brod, 2016; Taber, 2015).

Some misconceptions of RR have been reported as given below. Activation energy is the amount of energy released during the reaction. Catalyst does not affect the reaction mechanism. A catalyst increases the reaction product. The rate of reaction increased 
with time (Cakmacki, 2010). The reaction rate will remain unchanged from the beginning to the end of the reaction; the reaction will be in high activation energy, and the possibility of collision to occur is small (Kolomuç \& Tekin, 2011). Catalyst can accelerate the rate of reaction; an increase in reactant concentration will cause a long reaction time (Kurt \& Ayas, 2012). Increasing the temperature of the irreversible reaction causes a decrease in the reaction rate because particle collisions become ineffective (Driel, 2002). These misconceptions must be eliminated before students' study concepts in CE.

There are many strategies used to eliminate misconceptions. One of them is a conceptual change strategy. This strategy has been implemented to reduce of misconceptions in CE (Atasoy et al., 2009; Canpolat et al., Chiu et al., 2002; Niaz, 1998a), chemical reaction equations (Stojanovska et al., 2012), nature of matter, atomic structure, chemical reactions, and stoichiometry (Regan et al., 2011), chemical bonds (Pabuccu \& Geban, 2006), and Acid-Base (Demircioglu et al., 2005). However, elimination carried out in a regular learning setting was less optimal in terms of efficiency in time and the use of students' contributions (Taber, 2002). Designing an innovative learning strategy to eliminate the misconception of prerequisite concepts is very important before learning the related concepts (Taber, 2015). This new learning strategy must be able to eliminate misconceptions optimally and produces a proper understanding of new related concepts. The learning strategy has the following characteristics. First, the learning strategy should start with identifying and eliminating the misconceptions of prerequisite concepts. One strategy that can be applied in reducing misconceptions is conflict cognitive. This strategy has proven effective in eliminating misconceptions in chemistry (Kang et al., 2010; Chi, 2008; Chiu et al., 2002; Limon, 2001; Niaz, 1998a).

Second, learning should stimulate the development of students' Scientific Reasoning Capability (SRC) optimally. This is important since SCR is required to understand the chemistry concept properly. Stimulation can be in the form of inquiry questions (Bybee et al., 2006). Third, learning involves macroscopic, submicroscopic, and symbolic representations. The interrelation of the three representations is believed to improve students' conceptual understanding (Talanquar, 2011) and reduce students' misconceptions (Santos \& Arroio, 2016).

Fourth, the learning strategy should emphasize the process of building a proper theoretical knowledge based on prerequisite concepts (Han, 2013). Building an appropriate understanding of concept involve some activities such as observing, interpreting, stimulating questions, scaffolding, reinforcement, and concept validation by teachers. Fifth, the learning emphasizes evaluation and reflection to gain information based on the assessment processes and results (Arends \& Kilcher, 2010). Based on the theoretical reviews and analyses of relevant research results, the learning strategy formulated involving four phases: 1) Engagement, 2) Modifications, 3) Building Concepts, 4) Evaluation-Reflection. A learning strategy having these characteristics is called EMBE-R strategy (Jusniar et al., 2019).

The strengths and novelty of EMBE-R strategy is the elimination of students' prerequisite misconceptions, increasing of students' SRC, involving three 
representations, and provide a strong foundation in understanding new related concepts. Elimination of prerequisite concepts done using cognitive conflict strategy. Increasing students' SRC facilitated by the frequent provision of quality intellectual stimulation to students. Three representations always used in discussing chemical phenomena. Elimination of prerequisite concepts provides a strong foundation in building new related concepts.

The present study addresses research questions: 1) Is the EMBE-R strategy more effective than a verification strategy in eliminating students' misconceptions of RR at different SRC? 2) Does the EMBE-R strategy produce a higher conceptual understanding of concepts in CE than verification strategy? Verification is one of the learning strategies that tend to be applied in chemistry learning in most schools in Indonesia.

\section{Context and Review Literatur}

The EMBE-R strategy philosophy developed by Jusniar et al. (2019) based on several learning theories such as information processing theory (Gagne, 2005), meaningful learning theory by Ausubel (Novak, 2002), constructivist theory by Piaget and Vigotsky (Berg, 2006), and theory of conceptual change (Carey, 2000). The innovative EMBE-R learning strategy based on inquiry learning. This learning emphasizes the process, generalization of concepts, and problem-solving through scientific means (Lamba, 2015). One inquiry-based learning that often used as a reference in the development of innovative learning models is the Learning Cycle (LC).

The three-phase LC model is the basis for Hanson et al. (2006) in developing a processoriented guided inquiry learning (POGIL) model. LC makes it easy for students to understand concepts and rearrange student knowledge. In its development, the threephase LC (verify, inform, and practice) by Atkins \& Karplus (in Cracolice, 2009) was later developed by Abraham \& Renner (1986) into five stages called LC-5E. The LC-5E (Engagement-exploration-explanation-elaboration and evaluation) stage is applied sequentially and repeatedly. According to Abraham \& Renner (1986), the sequences of these stages will be effective for the development of conceptual understanding and improvement of students' thinking abilities. The LC-5E stages (Bybee et al., 2006), which were modified and integrated with the cognitive conflict strategy stage, produced four stages of the EMBE-R strategy. This strategy has very high validity and high practicality.

The class starts with the engagement stage intended to engage students physically and mentally in the learning process by exploring their understanding of prerequisite concepts. This based on information processing theory about the importance of motivation at the beginning of learning (Gagne et al., 2005). Activities at this stage are: 1) Prepare students physically and mentally for learning, accompanied by motivation. 2) Explore the concept of prerequisites. The concept of this prerequisite may be a misconception or incomplete understanding. 3) Delivering indicators of competency achievement.

The next is a modification stage intended to produce a proper understanding of the prerequisite concept by eliminating their misconceptions, if any. However, if there is no 
misconception, then the process of assimilating the concept occurs. Based on Piaget and the modified method by Toulmin (Duit \& Treagust, 2003), modifications occur if students' understanding of prerequisite concepts is not sufficient to reach the new one. So, students need to rearrange or modify their conceptions. The process involves accommodation from dis-equilibrium to equilibration condition based on conceptual change theory with cognitive conflict strategy (Kang et al., 2010; Chi, 2008; Bilgin \& Uzuntiryaki, 2003; Chiu et al., 2002; Limon, 2001). Activities at this stage are: 1) Creating conflict conditions for students by providing experimental results in the form of graphs or tables (confrontation). 2) Giving questions as scaffolding to straighten out the wrong concept (resolve). 3) Reconstructing understanding into correct prerequisite concepts. The activities carried out if students had misconceptions about prerequisite concepts. But if students only lack an understanding of concepts, then they are given stimulation questions to remind their prerequisite concepts and to assimilate them into correct understanding.

The building concept stage adapted from the constructivist idea of Piaget \& Vigotsky (Berg, 2006). This stage intends to make a proper conceptual understanding of students with the right theoretical prerequisites. Tries to involve students actively and collaboratively to make meaningful learning (Novak, 2002), and the information received could be stored in the students' long-term memory (Gagne et al., 2005). Activities at this stage are: 1) Observing and analyzing experimental data in the form of tables, animated videos, and graphs. 2) Discuss in groups and write down their observations and analysis on a worksheet. 3) Answering stimulus questions to build concepts. 4) Discuss the findings of each group to unite students' understanding. 5) Summarizing the results of the discussion. 6) Strengthening and expanding the concept with practice questions. 7) Communicating and summarizing the results of discussions in the group. 8) Validate the acquisition of concepts.

Finally, the evaluation-reflection stage intended to measure students' achievement. This stage can be used by the teacher to reflect and evaluate the learning process (Arends \& Kilcher, 2010; Fry et al., 2009). Activities at this stage are: 1) Providing individual tests. 2) Asking students to do a self-assessment of the results obtained as self-reflection material for students. 3) Validate the results that have been obtained.

The four stages of the strategy have the strengths of which 1) instilling a proper understanding of the prerequisite concept. 2) building an understanding of concepts with cooperative systems. 3) maximizing inquiry questions to stimulate students' intellectuals. 4) optimizing the use of animation media, graphics, and tables to support understanding of three levels of representation. 5) performing validation and reflect the accuracy of students' understanding of concept achievement. It expected to make students 'understanding intact and meaningful to improve understanding of students' chemical concepts.

\section{METHOD}

\section{Research Design}

Sample of this study consist of 70 students majoring in Natural Science from two classes in a senior high school in Gowa, South Sulawesi, Indonesia, taken from eight 
homogenous groups in the school. Experimental Class (EC) consisting of thirty-five students subjected to the learning process using the EMBE-R strategy. The Control Class (CC) that also included thirty-five students is subjected to the learning process using verification strategy. Initial Ability Test (IAT) and Three-tier Reaction Rate Diagnostic Tests (TRRDT) were giving to both groups before the learning implementations.

Students' IAT score used to ensure the homogeneity of the sample to fulfill a condition for testing effectiveness in a quasi-experimental setting. The efficacy of the EMBE-R strategy tested in two designs, namely descriptive and quasi-experimental (See Figure 1). The descriptive design was used to examine the effectiveness of the EMBE-R strategy to eliminate students' misconceptions of RR, that is, by comparing the percentages of eliminations experienced by students in the control and the experimental class following the Hake category (Hake, 1998). Three criteria of misconception elimination developed by Hake given in Table 1.

Table 1

The criterion of misconception elimination

\begin{tabular}{ll}
\hline The proportion of elimination of misconceptions $(\%)$ & Criterion \\
\hline $71.0-100.0$ & High \\
\hline $41.0-70.0$ & Medium \\
\hline $0.00-40.0$ & Low \\
\hline
\end{tabular}

This study applied a quasi-experimental design for comparing students' understanding of concepts in $\mathrm{CC}$, such as given in Table 2.

Table 2

Quasi-experimental design to compare students' conceptual understanding in CE (adapted from Creswell, 2012)

\begin{tabular}{lll}
\hline Subject & Treatment & Post-test \\
\hline Experimental Class & EMBE-R strategy & O1 \\
\hline Control Class & Verification strategy & O1
\end{tabular}

This study was conducted in 16 class meetings from August to October 2018, with a duration of 90 minutes for each meeting. The topic taught was CE. The implementation of the EMBER strategy for experiment class follows the following four stages. Stage one is engagement. In this stage, students were prepared both physically and mentally to learn, exploring the prerequisites concepts, and identifying possible misconceptions. Stage two is a modification. In this stage, misconceptions of the prerequisite concept in the rate of reaction are eliminated using cognitive conflict strategy. Stage three is building a new concept related to the chemical equilibrium topic. In this stage, students observe data or animated videos, analyze, and discuss with their group members. Students built a new concept based on an inquiry strategy with minimal help from the teacher.

Stage four is evaluation and reflection. In this stage, a short test was given to students at the end of every meeting to assess students' achievements. Improper concept revision 
was also done at this stage. The implementation of verification strategy for control class involved teacher's explanation of a concept, laboratory work for verification of concepts followed with class discussion, and assessment.

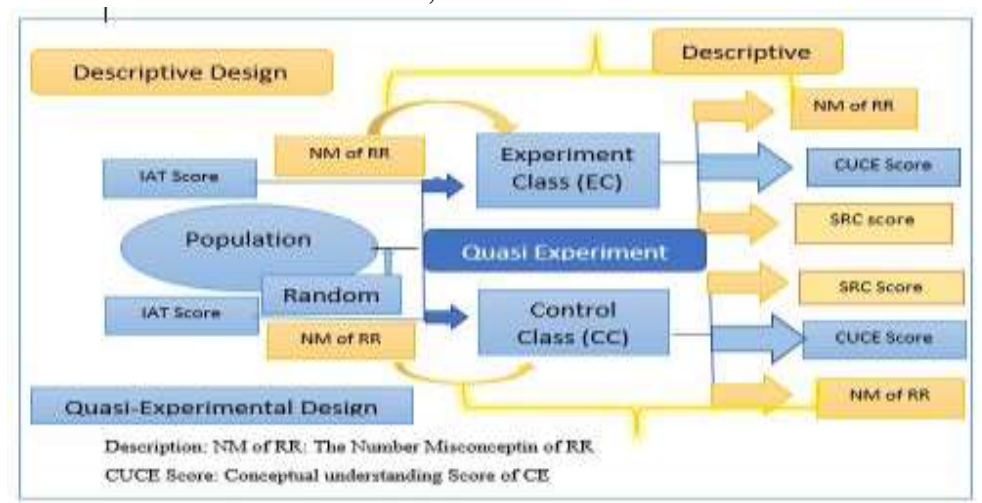

Figure 1

Quasi-experimental and descriptive design diagram

\section{Instrument}

\section{Initial Ability Test (IAT)}

The Initial Ability Test (IAT) was an objective test consisting of 25 items (six items about moles concept and reaction equations, two items about ideal gas, two items about exothermic and endothermic reactions, and 15 items about reaction rates and factors influencing the reaction rate). The content validity of this test judged by three experts and three practitioners was $90.7 \%$, included in the very high category. A reliability coefficient of this test, calculated by Cronbach Alpha formula, was 0.81, include the upper-grade category. Trial of the test on 36 students from different schools indicated that all of the item's tests were valid with item validity in the range of 0.34 to 0.62 .

The IAT was used to test the similarity of the initial abilities of the two groups, as a condition for quasi-experimental design.

\section{Three-tier Reaction Rate Diagnostic Tests (TRRDT)}

The Three-tier RR Diagnostic Test (TRRDT) consists of 15 items. The first-tier of each item consists of four possible answers. Second-tier consists of four possible reasons for each answer selected in the first tier. Third-tier is about the confidence level of students in answering the first and second tiers. They are three categories of confidence level, namely guessing, not sure, and sure.

The TRRDT has an average content validity of $90.7 \%$, which is in the very high category. A reliability coefficient of this test, calculated by Cronbach Alpha formula, was 0.78 , include the high category. Trial of the test on 36 students from different schools indicated that all of the items were valid is in the range of 0.35 to 0.72 . 
Students experiencing misconceptions in the concept of RR were determined based on criteria developed by Arslan et al. (2012). Students' answers might be included in one of three categories, namely 1) correct answers, wrong reasons, and sure; 2) wrong answers, correct reasons, and sure; 3) wrong answers, wrong reasons, and sure. TRRDT were giving to both groups, before and after the learning implementations.

\section{Classroom Test of Scientific Reasoning (CTSR) Translation}

The SRC test used is a translated version of the CTSR developed by Lawson et al. (2000). The test consists of 24 items with distribution, as follows. Four items about conservation thinking, four questions about proportional reasoning, two items about control of variable, four items about probability reasoning, two items about correlation reasoning, and four items about hypothetic-deductive thinking (Han, 2013). The Indonesian version of this test has a reliability coefficient, calculated by Cronbach Alpha formula, of 0.75 .

\section{Conceptual Understanding of Chemical Equilibrium Test (CUCET)}

The CUCET is a subjective test consisting of 10 items. This test is used to measure students' understanding of concepts in chemical equilibrium material. The concepts measured are dynamic equilibrium, homogeneous and heterogeneous equilibria, degree of dissociation, equilibrium constant, a relationship of $\mathrm{Kp}$ and $\mathrm{Kc}$, factors that affect the shift in equilibrium shift such as concentration, the volume of gas, temperature, and catalysts, and chemical equilibrium application in industry.

Based on assessments given by three experts and three practitioners, it was found that the test had content validation of $95.7 \%$, included in the high category. This test has a reliability coefficient, calculated by Cronbach Alpha formula, of 0.83 , included in the high category. The result of the trial of this test on 36 students indicated that all of the items test items are valid with item validity in the range of 0.31 to 0.72 .

\section{Data Analysis}

Students' initial ability is based on the IAT score test collected for experimental and control classes. The test of initial students' ability used t-test for an independent sample. Prior to the test, normality and homogeneity test are performed. Data on misconception elimination is expressed in the percentage of elimination calculated using the following formula.

$$
\% E=\frac{x}{n} \times 100 \%
$$

$\% E=$ percentage of elimination misconception

$X=$ the difference between the number of students with misconceptions before and after

$$
\text { treatment }
$$

$\mathrm{n}=$ number of students having misconception before treatment 
The average percentage of misconception elimination is calculated using the following formula.

$$
\%_{\bar{E}}=\frac{E\left[E \times{ }^{2} \bar{E}\right)}{E E}
$$

$E$ : The number of misconceptions eliminated (difference in misconception before and after learning).

$\% E$ : percentage of elimination for each misconception

$\Sigma E$ : total number of misconceptions eliminated

$\% \bar{E}$ : average percentage of misconception elimination

The effectiveness of EMBE-R and verification strategies in eliminating misconception is based on the percentage of misconception eliminated, and criteria developed by Hake described above. Effectiveness of misconception elimination is also compared for students having high and low SRC. Students having SRC score the same or higher than the average score are included in the high SRC group, whereas students having SRC score lower than the average score are included high SRC group, whereas students (Bridges \& Harnish, 2015).

The effectiveness of EMBE-R strategy compared to the verification strategy in producing an understanding of concepts in CE is based on a score of CUCET. The score of CUCET collected from experimental and control classes is subjected to a t-test.

\section{RESULTS}

\section{Results of Initial Ability Test}

Normality test of IAT score for experimental and control classes is given in Table 3

Table 3

Summary of normality test of initial ability test (IAT) score

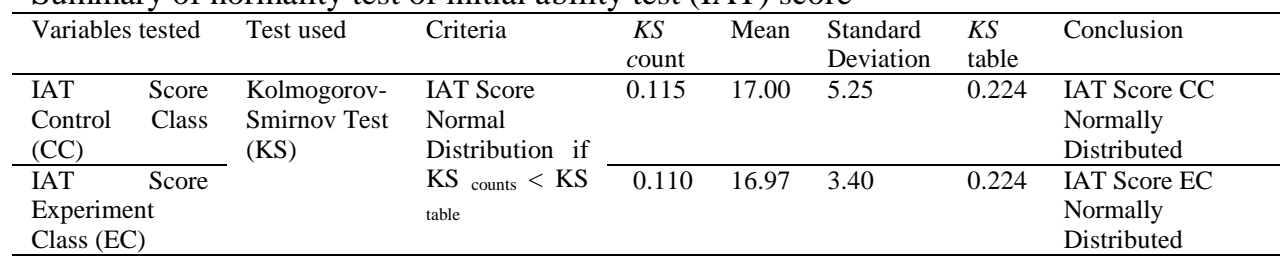

Homogeneity test of IAT score is summarized in Table 4

Table 4

Summary of homogeneity test initial ability test (IAT) score

\begin{tabular}{llllll}
\hline Variables tested & Test used & Criteria & $F_{\text {count }}$ & $F_{\text {table }}$ & Conclusion \\
\hline Score IAT CC - & Levene's test & Variance & 3.49 & 3.98 & CC-EC have \\
EC & Statistic & homogeneous if & & & homogeneous of \\
& & $F_{\text {count }}<F_{\text {table }}$ & & & variance \\
\hline
\end{tabular}

Result of $t$-test the IAT score is summarized in Table 5. 
Table 5

Summary of $t$-test of the initial ability test (IAT) score

\begin{tabular}{llllll}
\hline Variables tested & Test Used & Test criteria & $t_{\text {count }}$ & $t_{\text {table }}$ & Conclusion \\
\hline IAT Score & $t$-test two & $\begin{array}{l}\text { Reject } \mathrm{H}_{\text {o, }} \text { if the } \\
\text { value of } \\
\text { CC - EC }\end{array}$ & 0.26 & 1.99 & $\begin{array}{l}\text { Accept } \mathrm{H}_{0} ; \text { meaning both } \\
\text { groups are the same }\end{array}$ \\
& tails & & & \\
\hline
\end{tabular}

Based on the results of the $t$-test given in Table 5, it appears that the $t_{\text {count }}$ is smaller than the $t$ table means that there is no significant difference between the control and experimental classes. Thus, students in both classes are homogeneous or have the same initial ability. Besides, the number and types of control and experimental misconceptions before treatment are the same (see Appendix 1). Thus, the effectiveness of this strategy can be seen from two aspects, namely: 1) The effectiveness of eliminating RR misconceptions. 2) The effectiveness of building an understanding of the concept of CE.

Result of Effectiveness of the EMBE-R Strategy to Eliminate Misconceptions of RR at the Different SRC Levels

Data in Appendix 1 shows there is a reduction in misconception by $72.3 \%$ for EC and by $40.8 \%$ for CC. The reduction of misconception in the experimental class is included in the high category, whereas for control class is included in the low category. This result indicates that the EMBE-R strategy is more effective in eliminating misconceptions in RR than the verification strategy.

Based on students' SRC, the percentage elimination misconception for both classes is given in Table 6.

Table 6

Elimination of misconceptions in RR for students with different level of SRC in the Experiment Class (EC) and Control Class (CC)

\begin{tabular}{|c|c|c|c|c|c|c|c|c|c|c|}
\hline \multirow{3}{*}{$\begin{array}{l}\text { Level } \\
\text { of } \\
\text { SRC } \\
\end{array}$} & \multirow{2}{*}{\multicolumn{2}{|c|}{$\begin{array}{l}\mathrm{N} \text { (Number } \\
\text { of } \\
\text { Students) }\end{array}$}} & \multicolumn{6}{|c|}{$\begin{array}{l}\text { The number of students with the category } \\
\text { of eliminating of misconception }\end{array}$} & \multicolumn{2}{|c|}{$\begin{array}{l}\text { Average of } \\
\text { Elimination }(\%)\end{array}$} \\
\hline & & & Hig & & $\mathrm{Mec}$ & um & Low & & & \\
\hline & $\mathrm{EC}$ & $\mathrm{CC}$ & EC & $\mathrm{CC}$ & $\mathrm{EC}$ & $\mathrm{CC}$ & $\mathrm{EC}$ & $\overline{\mathrm{C}}$ & $\mathrm{EC}$ & $\overline{\mathrm{C}}$ \\
\hline High & 18 & 16 & 9 & 4 & 8 & 4 & 1 & 12 & 76.7 & 61.1 \\
\hline Low & 17 & 19 & 7 & - & 8 & 6 & 2 & 13 & 72.3 & 32.4 \\
\hline
\end{tabular}

Description: High SRC Score CC $\geq$ mean (10.3); EC $\geq$ mean (12.0)

Regardless of the treatment used, data in Table 6 indicate that the percentage reduction of misconception in RR for students with high SRC levels is greater than that of students with low SRC levels. This indicates that elimination of misconceptions is easier for students with high SRC levels than that of a lower one.

Result of the Effectiveness of EMBE-R and Verification Strategies in Generating Concept Understanding in Chemical Equilibrium Material

Result of the Effectiveness of EMBE-R and verification strategies in generating concept understanding in chemical equilibrium material 
The effectiveness of the two strategies based on the score of students' learning outcomes. The higher the score of students' learning outcomes, the higher the students' understanding of the concepts in chemical equilibrium material. A score of students' learning outcome was collected using CUCET. The CUCET scores of experimental and control classes are given in Table 7.

Table 7

CUCET score of experimental and control classes

\begin{tabular}{llll}
\hline Class & $\mathrm{N}$ & Mean & Standard Deviation \\
\hline Experiment & 35 & 73.8 & 9.6 \\
\hline Control & 35 & 62.4 & 10.5 \\
\hline
\end{tabular}

Result of the normality test of CUCET scores of experimental and control classes are summarized in Table 8.

Table 8

Normality test of CUCET score of control and experiments classes

\begin{tabular}{lllllll}
\hline Variable tested & Test used & Criteria & Mean & $\begin{array}{l}\text { KS } \\
\text { count }\end{array}$ & $\mathrm{KS}_{\text {table }}$ & Conclusion \\
\cline { 1 - 3 } $\begin{array}{l}\text { Score CUCET } \\
\text { of (CC) }\end{array}$ & $\begin{array}{l}\text { Kolmogorov- } \\
\text { Smirnov Test }\end{array}$ & $\begin{array}{l}\text { CUCET Score } \\
\text { Normal }\end{array}$ & 62.4 & 0.094 & 0.224 & $\begin{array}{l}\text { The score of CUCET } \\
\text { CCC normally distributed }\end{array}$ \\
\cline { 1 - 3 } $\begin{array}{l}\text { Score CUCET } \\
\text { of (EC) }\end{array}$ & KS) & $\begin{array}{l}\text { Distribution If } \\
K S_{\text {count }}<K S_{\text {table }}\end{array}$ & 73.8 & 0.109 & 0.224 & $\begin{array}{l}\text { The score of CUCET } \\
\text { EC normally distributed }\end{array}$ \\
\hline
\end{tabular}

Description: CUCET score: Student scores on tests of conceptual understanding of CE

Data in Table 8 shows that the CUCET score of experiment and control classes are normally distributed. Result of the homogeneity test of CUCET scores of experimental and control classes are summarized in Table 9.

Table 9

Summary of homogeneity test of CUCET score for CC and EC

\begin{tabular}{llllll} 
Variable tested & Test used & Criteria & $F_{\text {count }}$ & $F_{\text {table }}$ & Conclusion \\
\hline The Score of & Levene's & Homogeneous & 0.053 & 3.98 & Variance CUCET CC- \\
CUCET CC - & Statistic & variance if & & & EC homogeneous \\
EC & Test & $F_{\text {count }}<F_{\text {table }}$ & & & \\
\hline
\end{tabular}

Data in Table 9 shows that CUCET scores of experiment and control classes have homogeneous variance. Result of $t$-test of CUCET scores of experimental and control classes are summarized in Table 10.

Table 10

The result of the $t$-test comparing the CUCET score of the control and experiments classes

\begin{tabular}{llllll}
\hline Variable Tested & Test used & Criteria & $t_{\text {count }}$ & $t_{\text {table }}$ & Conclusion \\
\hline The Score of & The $t$-test & Reject $\mathrm{H}_{0}$ if & -5.32 & 1.99 & $\begin{array}{l}\text { Reject } \mathrm{H}_{0} \text {; meaning the two } \\
\text { groups are different }\end{array}$ \\
CUCET CC-EC & of two tails & $t_{\text {count }}>t_{\text {table }}$ & & &
\end{tabular}

Description: $t_{\text {count }}$ is the absolute value

Data in Table 10 shows a significant difference in the CUCET score of experimental and control classes. The experimental class has a greater CUCET score than CC. This 
indicates that the students' in EC has a better understanding of concepts in CE than the CC. Based on students' SCR level, the CUCET scores of experimental and control classes are given in Table 11.

Table 11

CUCET scores of experimental and control classes based on students SCR level

\begin{tabular}{|c|c|c|c|c|c|c|}
\hline \multirow[t]{2}{*}{$\begin{array}{l}\text { Level of } \\
\text { SRC }\end{array}$} & \multirow[t]{2}{*}{$\begin{array}{l}\mathrm{N} \\
\mathrm{EC}\end{array}$} & \multicolumn{2}{|c|}{$\begin{array}{l}\text { The number of students with the } \\
\text { category of conceptual } \\
\text { understanding of EC }\end{array}$} & \multirow[t]{2}{*}{$\begin{array}{l}\mathrm{N} \\
\mathrm{CC}\end{array}$} & \multicolumn{2}{|c|}{$\begin{array}{l}\text { The number of students with the } \\
\text { category of conceptual } \\
\text { understanding of CC }\end{array}$} \\
\hline & & High (\%) & Low $(\%)$ & & High $(\%)$ & Low $(\%)$ \\
\hline High & 18 & $14(40.0)$ & $4(11.4)$ & 16 & $7(20.0)$ & $9(25.7)$ \\
\hline Low & 17 & $7(20.0)$ & $10(28.6)$ & 19 & $4(11.4)$ & $15(42.9)$ \\
\hline
\end{tabular}

Description: High SRC EC (Score $\geq$ mean (12.0); CC Score $\geq$ mean (11.0))

High CU if the CUCE score is $\geq 70$

Regardless of the learning strategy used, data in Table 10 shows that students with high SCR levels have a higher CUCET score than students with low SCR levels. This indicates that students with high SCR levels have a better understanding of concepts in CE than students with low SCR levels. Based on the description given above, it can be concluded that the EMBE-R strategy produces a better understanding of concepts in CE material than the verification strategy.

\section{DISCUSSION}

The Effectiveness of the EMBE-R Strategy for Eliminating RR Misconception in the different SRC

EMBE-R Strategy has effectively eliminated students' misconceptions, which is observable from the average percentage of eliminations that occurred in the experimental class, which is significantly higher than that of the control class (See Appendix 1). Based on Hake's category, the elimination of misconceptions included in the high category for EC and low category for CC. The result indicates that the EMBE$\mathrm{R}$ strategy is more effective in eliminating misconceptions than verification energy. EMBE-R strategy involves a cognitive conflict strategy in eliminating misconceptions, whereas the verification strategy involves direct explanation. The superiority of the EMBE-R strategy compared to the verification strategy lies in the modification stage. EMBE-R strategy consists of a modification phase, whereas the verification strategy does not.

During this phase, students in the EMBE-R class need to deal with a cognitive conflict against their misconceptions. The conflicts embedded through displaying media presentations of experimental data or animated videos that are contradictory to students' misconceptions (Chiu et al., 2002). The data are accompanied by inquiry questions. The questions provided in addition to making the dis-equilibrate state also stimulate the development of students' scientific reasoning capability (SRC). So, students would realize there is a problem with their understanding, which leads them into a state of disequilibration. The situation would not last long as it will be equilibrated back with selfregulation (Limon, 2001) and students' reasoning abilities development (Lawson, 2004). 
The latter will support students' thinking abilities, which might easy them to understand the concept. According to Zimmerman (2007), students can develop their intellectuals if they often face statements that will facilitate the process of understanding concepts and elimination of misconceptions.

The cognitive conflicts presented must be specific to any type of misconception. Cognitive conflicts ensure students to reconstruct their misconceptions. This process takes strong effort, especially in stimulating the dissatisfaction of creating anomalies so that students become dissatisfied with their false understanding (Carey, 2000). If the misconception is not immediately eliminated, it will interfere with learning in a related concept (Durmaz, 2018; Papaphotis \& Tsaparlis, 2008).

Elimination of misconception in students with high scientific reasoning capability (SRC) is easier than in students with low reasoning capability. This seems to be caused by the ease with which students with high SCR change their understanding of concepts compared to students with low SCR. The result of this study corresponds to the study reported by Lawson \& Thomson (1988). They found that there is a negative correlation between SRC and the number of students' experience misconceptions in sains topic. The higher the level of SCR students, the fewer misconceptions they experience. Lawson (2004) argues that the high level of SRC students has been able to think correlation, combination, probability, and hypothetic deductive, where students can analyze and choose a more sensible and correct concept.

\section{The Effectiveness of EMBE-R and Verification Strategies in Generating Understanding of Concepts in Chemical Equilibrium Material}

Data in Table 7 indicates that the EMBE-R strategy produces a better understanding of concepts in Chemical Equilibrium than verification strategy. The explanation of this result may be given below.

As explained above, the ability of the EMBE-R strategy to eliminate misconceptions in $\mathrm{RR}$ material is higher than the verification strategy. Thus the possibility of students involved in learning with the EMBE-R strategy to understand related concepts in CE material tends to be better than those involved in verification strategy. As a result of $\mathrm{CE}$ material learning, students involved in the EMBE-R strategy have a better understanding than students involved in the verification strategy.

In learning with the EMBER-R strategy, students develop concepts with minimal assistance from the teacher. This assistance is in the form of inquiry questions. This inquiry questions are quality intellectual stimulation that can encourage the development of students' SRC. In learning with verification strategy, students do not build the concepts learned. Concepts are accepted directly by students from the teacher or other learning resources. Thus students lack the intellectual stimulation needed for the development of their SRC. Therefore the EMBE-R strategy tends to result in higher students' SRC development compared to the verification strategy. As a result, the ability of students who taught with the EMBE-R strategy to understand concepts in CE tends to be better than the ability of students who taught with verification strategy. The effectiveness of EMBE-R and verification strategies in generating an understanding of 
concepts in CE material may also be related to minimum completeness criteria. The standard of competency achievement based on the Chemistry Curriculum in Indonesia, learning considered successful if as many as score 70 or more than a total score of 100 . EMBE-R strategy produces $60.0 \%$ of students achieving minimum completeness criteria, whereas the verification strategy produces only $31.4 \%$ of students achieving minimum completeness criteria. This also indicates that the EMBE-R strategy provides a better understanding of concepts in CE material than verification energy. A good understanding of student concepts shows indications of having great learning outcomes. The relevant research has been reported by Akinwumi \& Bello (2015) that learning LC and inquiry can improve student learning outcomes.

This success certainly supported by one of the activities at the building stage, namely students in groups observing, analyzing animated videos, and doing a worksheet. The teacher's role is as a facilitator, mediator, and to provide a guide to a minimum in the learning process. The relevant research has been conducted by Eymur \& Geban (2017) by applying cooperative learning and conceptual change to the chemical bonding material. His findings that collaborative learning accompanied by a conceptual change to the prevalence of the chemical bonds misconceptions can enhance the understanding of student concepts. This process, based on inquiry learning, can make students active in the classroom. This learning helps students learn in a fun way and helps them gain depth about concepts (Zubaidah et al., 2017). Another advantage is that it provides an opportunity for students to find ideas in making their concepts based on concepts that have been previously (Pedaste et al., 2015).

The EMBE-R strategy seeks to maximize the use of media to build knowledge of the interconnectedness of three levels of representation, namely macroscopic, submicroscopic, and symbolic. According to Bawden (2015), the important thing in building an understanding of the right chemical concept is the success of connecting concepts and interrelationships of three levels of representation. The representation between these relationships intended to know the causal relationship of a concept (Binder et al., 2016). Santos \& Arrio (2016) reported the effectiveness of media use and interrelationships of three levels of representation to improve students ' understanding of the equilibrium system and reduce the equilibrium chemical misunderstanding.

In this strategy, validation and reflection carried out simultaneously to produce a proper understanding of the CE concept. As Osborne \& Wittrock (1983) suggested that learning that seeks to link several concepts can make students validate the concepts they construct. According to Effendy (2002), validation is an important activity in learning to find out whether the understanding that has formed in students' thinking is compatible with the understanding agreed upon by the scientific community.

\section{CONCLUSION AND IMPLICATION}

The EMBE-R strategy is more effective in eliminating students' misconceptions in RR than verification strategy at a high and low-level SRC. This indicated a percentage of misconceptions eliminated. For high and low SRC, elimination of misconceptions in the experimental class is included in the high category while for control class is included 
moderate and low category. Elimination of misconception for students with high scientific reasoning capabilities is easier than students with low scientific reasoning capabilities. The EMBE-R strategy produces a better understanding of concepts in CE than the verification strategy.

The limitation of this study is that SRC is placed as a moderator variable and is tested only after learning. Further research can be done as an improvement by giving the SRC test before and after learning with the EMBE-R strategy. Thus, testing the effectiveness of this strategy to develop SRC can be a complement to this finding.

The implementation of the EMBE-R strategy contributes to the world of education to produce students who have a meaningful and comprehensive understanding of chemical concepts. This strategy is expected to be widely implemented by education practitioners (chemistry teachers). The proper understanding of prerequisite concepts is very important, as are the characteristics of interconnected chemical concepts. Misunderstandings in the prerequisite concepts will result in a failure to understand the related concepts. This strategy is based on a group and inquiry system so that it can foster positive habits such as the courage to argue, collaborate, create, and care for one another. In the end, it will have a positive follow-up effect on social life.

\section{REFERENCE}

Abraham, M. R., Williamson, V. M., Westbrook, S. L., \& Carolina, N. (1994). A crossage study of the understanding of five chemistry concepts. Journal. Research and Science Teaching, 31(2), 147-165.

Abraham, M., R. \& Renner, J. W. (1986). The sequence of learning cycle activities in high school chemistry. Journal of Research in Science Teaching, 23(2), 121-143.

Akinwumi \& Bello. (2015). Relative effectiveness of the learning-cycle model and inquiry teaching approach in improving student's learning outcomes in physics. Journal of Education and Human Development, 4(3), 169-180.

Ambrose, S. A., Bridges, M. A., Dipietro, M., Lovet, M. C., \& Norman, M. K. (2010). How does learning works? New York, NY: Jossey Bass Willey Imprint.

Arends, R., \& Kilcher, A. (2010). Teaching for student learning becoming accomplish teacher. New York, NY: Taylor \& Francis.

Arslan, H. O., Cygdemoglu, C., \& Moseley, C. (2012). A three-tier diagnostic test to assess pre-service teachers' misconceptions about global warming, greenhouse effect, zone layer depletion, and acid rain. International Journal of Science Education, 34(11), 1667-1686.

Atasoy, B., Akkus, H., \& Kadayifci, H. (2009). The effect of a conceptual change approach on the understanding of student chemical equilibrium concept. Research in Science and Technology Education, 27(3), 267-282. 
Barke, H. D., Hasari, A., Yitbarek, D. (2009). Misconceptions in chemistry: Addressing perception in chemical education, book chapter, 145-170. Berlin, Heidelberg: SpringerVerlag.

Bawden, D. (2015). Storing wisdom: Chemical concepts and chemoinformatics. Informatics, 2, 50-67.

Berg, D.K.C. (2006). The status of constructivism in chemical education research and its relationship to the teaching and learning of the concept of idealization in chemistry. Foundation od Chemistry, 8, 153-176. DOI 10.1007/s10698-006-9010-1

Bilgin, İ., \& Uzuntiryaki, E. (2003). Student's misconceptions on the concept of chemical equilibrium. Education of Science, 28(127), 10-17.

Binder, J. R., Conant, L. L., Humphries, C. J., Fernandino, L., Simons, S. B., Aguilar, M. \& Desai, R. H. (2016). Toward a brain-based componential semantic representation. Cognitive Neuropsychology, 33(3-4), 130-174.

Bird, L. (2010). Logical reasoning ability and student performance in general chemistry. Journal of Chemical Education, 87/5, 541-546.

Bridges, R., K. \& Harnish, R. J. (2015). Gender differences in formal thinking: Their impact on the right-wing authoritarianism and religious fundamentalism. Psychology 6, $1676-1684$.

Bybee, R., Taylor, J. A., Gardner, A., Van Scotter, P., Carlson, J., \& Westbrook. (2006). The BSCS 5E instructional models: Origins and effectiveness. Colorado: Springer.

Cakmacki, G. (2010). Identifying alternative conceptions of chemical kinetics among secondary school and undergraduate students in Turkey. Journal of Chemical Education, 87(4), 449 -455.

Canpolat, N., Pinarbasi, T., Bayracheken, S., \& Geban, O. (2006). The conceptual change approach to teaching chemical equilibrium. Journal Research in Science and Technological Education, 24(2), 217-235.

Carey, S. (2000). Science education as conceptual change. Journal Applied Development Psychology, 21(1), 13-19.

Chiu, M. H., Chou, C. C., \& Liu, C. J. (2002). Dynamic processes of conceptual change: Analysis of constructing mental models on chemical equilibrium. Journal of Research in Science Teaching, 39(8), 688-712.

Chi, M. T. H. (2008). Three types of conceptual change: Belief revision, mental model transformation, and categorical shift, handbook of Research Conceptual Change, (6188). Hillsdale, NJ: Erlbaum.

Creswell, J. W. (2012). Educational research: Planning, conducting, and evaluating quantitative and qualitative research. $4^{\text {th }}$ Edition. New York, NY: Pearson. 
Demircioglu, G., Ayas, A., \& Demircioglu, H. (2005). Conceptual change achieved through a new teaching program on acids and bases. Education in Chemistry, 6(1), 3651 .

Dostál, J. (2015). "The definition of the term "inquiry-based instruction." International Journal of Instruction, 8(2), 69-82.

Duit, R., \& Treagust, D. F. (2003). Conceptual change: A powerful framework for improving science teaching and learning. International Journal of Science Education, 25(6), 671-688.

Durmaz, M. (2018). Determination of prospective chemistry teachers' cognitive structures and misconceptions about stereochemistry. Journal of Education and Training Studies, 6(9), 13-20. https://doi.org/10.11114/jets.v6i9.3353

Effendy. (2002). Efforts to overcome conceptual errors in chemistry teaching using cognitive conflict strategies. Media Komunikasi Kimia, 6(2), 1-22.

Ertmer, P. A., Driscoll, M. P., \& Wager, W. W. (2003). The legacy of Robert Mills Gagne.Zimmerman, B., J. \& Schunk, D. H (Eds), Educational Psychology: A century of contribution, a project of division 15 (Educational Psychology) of the American Psychological Association. Mahwah, New Jersey, NJ: Lawrence Erlbaum Associates, Inc.

Eymur, G., \& Geban, Ö. (2017). The collaboration of cooperative learning and conceptual change: Enhancing the students' understanding of chemical bonding concepts. International Journal of Science and Mathematics Education, 15(5), 853871.

Finley, F. N., Stewart, J., \& Yarroch, W. L. (1982). Teachers' perceptions of important and difficult science content. Science Education, 66(4), 531-538.

Fry, H., Ketteridge, S., \& Marshall, S. (2009). Glossary in Heather Fry, Steve Ketteridge \& Stephani Marshall (Eds). A handbook for teaching and learning in higher education enhancing academic Practice, 499-512. London, L: Routledge.

Gagne, R. M., Wager, W. W., Golas, K. C., \& Keller, J. M. (2005). Principle of instructional design. Fifth Edition. United States, UK: Thomson Wadsworth.

Ganesen, S., \& Shamuganathan, S. (2017). The effectiveness of physics education technology (PhET) interactive simulations in enhancing matriculation students' understanding of chemical equilibrium and remediating their misconceptions. Overcoming Students' Misconceptions in Science, 157-178. DOI. 10.1007/978-981-103437-4_9.

Gurcay, D. \& Gulbas, E. (2018). Determination of factors related to students' understandings of heat, temperature, and internal energy concepts. Journal of Education and Training Studies, 6(2), 65-72. 
Hake, R. R. (1998). Interactive-engagement versus traditional methods: A six-thousand student survey of mechanics tests data for introductory physics courses. American Journal of Physics, 66(1), 64-74.

Han, J. (2013). Scientific reasoning: Research, development, and assessment. A Dissertation of the Ohio State University.

Hanson, D. M., Bunce, D., Creegan, F., Moog, R., Padwa, L., Spencer, J., ... Wolfskill, T. (2006). Instructor's guide to guided-inquiry learning by With Contributions from other POGIL project personnel: Instructor 's guide to process-Oriented GuidedInquiry Learning. Lisle, IL: Pacific Crest.

Herron, J. D. (1996). The chemistry classroom formula for successful teaching. Washington, DC: American Chemical Society.

Ilyas, A., \& Saeed, M. (2018). Exploring teachers' understanding about misconceptions of secondary grade chemistry students. International Journal for Cross-Disciplinary Subject in Education, 9(1), 3323-3328.

Jusniar, J., Effendy, E., Budiasih, E., \& Sutrisno, S. (2019). The misconceptions of stoichiometry and its impact on the chemical equilibrium. Advance in Social Science, Education, and Humanities Research, 227: 138-141.

Jusniar, J., Effendy, E., Budiasih, E., \& Sutrisno, S. (2019). Development of EMBE-R learning strategy to prevent students' misconceptions on chemical equilibrium. Jurnal Sainsmat, VIII/I, 8-28.

Kang, H., Lawrence, C. S., Kang, S., \& Noh, T. (2010). Cognitive conflict and situational interest as a factor influencing conceptual change. International Journal of Environmental and Science Education, 5(4), 383-405.

Karpudewan, M., Treagust, D. F., Mocerino, M., Won, M., \& Chandrasegaran, A. L. (2015). Investigating high school students' understanding of chemical equilibrium concepts. International Journal of Environmental and Science Education, 10(6), 845863.

Kolomuç, A., \& Tekin, S. (2011). Chemistry teachers' misconception concerning the concept of chemical reaction rate. Eurasian Journal Physic Chemical Education, 3(2), 84-101.

Kurt, S., \& Ayas, A. (2012). Improving students' understanding and explaining real-life problems on concepts of reaction rate by using a four-step constructivist approach. Energy education science and technology part B. Social and Educational Studies, 4(2), 979-992.

Lamba, R. S. (2015). Inquiry-based student-centered instruction. ChemistryEducation: Best Practices, Opportunities, and Trends, 301-318. 
Lawson, A., E. \& Thompson, L. D. (1988). Formal reasoning ability and misconceptions concerning genetics and natural selection. Journal of Research in Science Teaching, 25(9), 733-746.

Lawson, A. E. (2004). The nature and development of scientific reasoning: A synthetic view. International Journal of Science and Mathematics Education, 2(3), 307.

Lawson, A. E., Clark, B., Cramer-Meldrum, E., Falconer, K. A., Sequist, J. M., \& Kwon, Y. J. (2000). Development of scientific reasoning in college biology: Do two levels of general hypothesis-testing skills exist? Journal of Research in Science Teaching, 37(1), 81-101.

Limon, M. (2001). On the cognitive conflict as an instructional strategy for conceptual change: A critical appraisal. Learning and Instruction, 11, 357-380.

Mary, J., S. \& Gumel, S. A. (2015). Effects of jigsaw model of cooperative learning on self-efficacy and achievement in chemistry among concrete and formal reasoners in colleges of education in Nigeria. International Journal of Information and Education Technology, 5(3), 196-199.

Niaz, M. (1998a). A Lakatosian conceptual change teaching strategy based on student ability to built models with varying degrees of conceptual understanding of chemical equilibrium. Journal of Science Education, 7, 107-127.

Novak, J. D. (2002). Meaningful learning: The essential factor for a conceptual change in limited or inappropriate propositional hierarchies leading to the empowerment of learners. Science Education, 86, 548 -571.

O'Connor, C. (2015). A practice-led approach to aligning learning theories with learning and teaching strategies in third level chemistry education. Irish Journal of Academic Practice, 4(1), article 7.

Osborne, R., J. \& Wittrock, M. C. (1983). Learning science: A generative process, Science Education, 67(4), 489-508.

Ozmen, H. (2008). Determination of students' alternative conceptions about chemical equilibrium: a review of research and the case of Turkey. Chemistry Education Research and Practice, 9(3), 225-233.

Pabuccu, A., \& Geban, O. (2006). Remediating misconceptions concerning chemical bonding through conceptual change text. Hacettepe University Journal of Education, 30, 184-192.

Papaphotis, G., \& Tsaparlis, G. (2008). Conceptual versus algorithmic learning in high school chemistry: The case of basic quantum chemical concepts part 2. Students' common errors, misconceptions, and difficulties in understanding. Chemistry Education Research and Practice, 9, 332-340. 
Pedaste, M., Mäeots, M., Siiman, L. A., De Jong T., Van Riesen, S. A. N., Kamp, E. T., Manoli, C. C., Zacharia, Z. C. \& Tsourlidaki, E. (2015). Phases of inquiry-based learning: Definitions and the inquiry cycle. Educational Research Review, 14, 47-61.

Regan, A., Childs, P., \& Hayes, S. (2011). The use of an intervention program to improve undergraduate students' chemical knowledge and address their misconceptions. Chemistry Education Research and Practice, 12, 219-227.

Santos, V.C \& Arroio, A. (2016). The representational levels: Influences and contributions to research in chemical education, Journal of Turkish Science Education, 13(1), 3-18.

Seery, M. K. (2009). The role of prior knowledge and student aptitude in undergraduate performance in chemistry: a correlation-prediction study. Chemistry Education Research and Practice, 10(3), 227-232.

Shing, Y., L. \& Brod, G. (2016). Effects of prior knowledge on memory: Implications for education. International Mind, Brain, and Educational Society, 1-9. https://doi.org/10.1111/mbe.12110.

Stojanovska, M. I., Petruševski, V. M., \& Šoptrajanov, B. T. (2012). Addressing students' misconceptions concerning chemical reactions and symbolic representations. Chemistry: Bulgarian Journal of Science Education, 21(6), 829-852.

Taber, K. S. (2015). Prior knowledge, book chapter: Encyclopedia of Science, 785-786. Dordrecht: Springer. doi.org/10.1007/978-94-007-2150-0_483.

Taber, K. S. (2009). Progressing science education: Constructing the scientific research program into the contingent nature of learning science. Dordrecht: Springer.

Taber, K. S. (2002). Chemical misconceptions-prevention, diagnosis, and cure: Theoretical background. London: Royal Society of Chemistry.

Talanquer, V. (2011). Macro, submicron, and symbolic: The many faces of the chemistry "triplet." International Journal of Science Education, 33(2), 179-195.

Van Driel, J. H. (2002). Students' corpuscular conceptions in the context of chemical equilibrium and chemical kinetics. Chemistry Education: Research and Practice in Europe, 3(2), 201-213.

Yakmaci-Guzel, B. (2013). Preservice chemistry teachers in action: An evaluation of attempts for changing high school students' chemistry misconceptions into more scientific conceptions. Chemistry Education Research and Practice, 14(1), 95-104.

Zimmerman, C. (2007). The development of scientific thinking skills. Development Review, 27(1), 65.

Zubaidah, S., Fuad, N. M., Mahanal, S., \& Suarsini, E. (2017). Improving the creative thinking skills of students through differentiated science inquiry integrated with a mind map. Journal of Turkish Science Education, 14(4), 77-91. 